\title{
Sustainability in Self Build Housing in Rural Area of Kedah, Malaysia
}

\author{
Wan Srihani Wan Mohamad' ${ }^{1}$ and Yahaya Ahmad² \\ Faculty of Built Environment, Universiti Malaya, 50603, \\ Kuala Lumpur, Malaysia \\ wswm47@yahoo.com ${ }^{1}$
}

\begin{abstract}
Communities face enormous challenges as their social, economic, and environmental resources are depleted and destroyed. Sustainable development represents a holistic way to achieve recovery and enhances the quality of life for everyone in these communities. This concept can be addressed through the development of local assets to revitalise economies, limit waste and pollution, improve the status of disadvantaged people, conserve natural resources, and promote cooperation and efficiency. Among the steps to facilitate the planning and actions by these stakeholders and become effective agents in achieving sustainability is the employment of self help approach to build houses. This paper attempts to provide an overview of the use of self help housing as an avenue to assist home ownership leading to the creation of sustainable community. It further attempts to uncover the responses from the rural households in Kedah (Malaysia) towards the concept of self build housing through the introduction of a simplified prefabricated system and to gather responses on the usage of the system.It is found that majority of the respondents had given positive responses in that the self build components were easily assembled not withstanding that this system introduced a new method to construct a house.
\end{abstract}

Keywords: Sustainable, self helphousing,self build, community empowerment

\subsection{INTRODUCTION}

Like most other developing countries, Malaysia is also facing problems of providing adequate shelter for a large portion of its people, especially the poor. Malaysia Government has extensively planned in building houses through public and private sector. Hundreds of thousands of houses have been formally constructed through both these sectors (Agus, 2001; Wan Mohamed, 2005 and Bakhtyar, 2013). Yet it would appear that the more and faster the houses are built, there are always more people requiring new houses year after year, making the formal sector incapable of satisfying the targeted needs.

Many organisations, government or private, had indeed looked into various aspects of reducing the cost of building these houses (Wan Mohamed, 2009). It either involved experimental houses built by new cheaper materials or redesigning the spatial arrangement of the existing tight spaces or involving high technology panels to be produced in mass amount or rezoning the low cost housing area outside city centre where price of land is cheaper. It is a known fact that the need for low cost housing is irrefutable but the question of what is the best approach sustainable enough for these houses to be built is an imperative debate since societies have diverse requirements for themselves. The understanding of the term sustainability itself has led to too many tenets ranging 
from production of sustainable materials, conserving energy, employing sustainable technology, listing factors that contribute to sustainable development etc. So how does one perceive sustainable?

Having reviewed the consideration for a cheaper way to construct houses through sustainable approach, this paper intends to provide an overview of the use of self help approach in construction as an avenue to assist home ownership leading to the creation of sustainable community. It further attempts to uncover the responses from the rural households towards the concept of self build housing through the introduction of a simplified prefabricated system and to gather responses on the usage of the system.

\subsection{WHAT IS SUSTAINABILITY?}

Generally, there is a commonly understood idea of sustainability - that is, the capacity for continuance into the long term. The most popular recent definition of sustainability can be traced to a 1987 United Nations Conference and states that sustainability in the context of development is: "Development that meets the needs of the present without compromising the ability of future generations to meet their own needs" (Brundtland, 1987).

How do we perceive sustainability in a community? Sustainable development represents a holistic way to achieve recovery and enhance the quality of life for everyone in any communities by developing local assets to revitalise economies, limiting waste and pollution, improving the status of disadvantaged people, conserving natural resources and promoting cooperation and efficiency (Serageldin, 1997). Harris and Borer (2005) agreed that sustainable development need to address social and economic as well as environmental considerations. Therefore it is right to make the link between housing and community; people and jobs; comfort and deprivation, whereby the complex interface between the physical fabric of a building and its impact on the people can be achieved.

\subsection{The Sustainability of Self Help Housing}

Many architects, engineers, authorities etc. are more concerned with the problems of underdevelopment; hence the dependency on innovative solutions of high technology. A search for an appropriate technology in self help housing does not require such solutions to emulate the efficient systems of machine age. It is therefore imperative to realise housing should be based on technologies that are suitable to local climate and social context.

Many researches concentrated on developing technologies, materials, development that are sustainable in many aspects. The value of sustainability through tangible evidence that can be measured by certain method is recognised. Amongst the methods used for housing are shown in the following examples. Alexander (1985) developed six (6) principles the community can apply as they build their own houses using locally available materials in Northern Mexico. Poh (2009) described how Zaldivar was inspired by mixing recyclable plastics with loofah turning them into panels for self help housing in Paraguay.

One particular technology that was demonstrated through housing projects in Thailand, Vietnam, Cambodia, Malaysia, Indonesia, Philippines, Laos, Myanmar, Sri Lanka, Papua New Guinea, Nepal and Fiji, is the SelfContained Housing Delivery System (SCHD) which consistently undercuts conventional construction systems by $30 \%$ to $50 \%$. This technology is used to produce affordable housing for middle and low income groups. Habitat Centre of AIT (1996), Bangkok has developed SCHD System using compatible building components by creating a complete modular interlocking building system especially well-suited for construction by unskilled labour. Eventually, the system may have socio-economic implications in a way that leads to an alternative approach to mass housing development. The practicality of the method might depend heavily on current economic and administrative frameworks of the country concerned. 
Self help houses as mentioned in many literatures have shown positive results that are too significant to ignore in providing housing for the poor. Yusoff (1993), Tan (1991) and Turner (1972) have concluded through various references that direct involvement by government on housing matters should be avoided and as an alternative, government should act as catalyst of inputs and provider of infrastructure rather than as a manufacturer of finished units. In developing countries, self help housing offers an alternative housing approach for its ability to provide adequate housing for a fast-growing nation. Self help is further associated with concepts that relate to intermediate technology as well as local scale production and organisation. The support from World Bank and Habitat has helped to organise many government to mobilise financial aid to assist self help housing projects.

Table 1 shows the various categories of self help housing across the world gathered from previous studies. Basically there are three main categories listed - Independent Self Help, Organised Self Help and Employed Self Help. All these types of self help categories have different aspects of involvements from the people who participate, skills, methods, time frame and supply/management of materials. It is crucial to distinguish and verify which category or which combination of categories that is acceptable in the Malaysian context for a successful self help housing provision.

Table 1: Summary of Self Help Housing Categories

\begin{tabular}{|c|c|c|c|c|}
\hline Authors & Details & $\begin{array}{l}\text { Abrams (1964); } \\
\text { Habraken } \\
\text { (1975); } \\
\text { Ward (1982) }\end{array}$ & $\begin{array}{l}\text { Turner (1975); } \\
\text { Ward (1982) } \\
\text { Tan (1992); } \\
\text { Keare\& Paris } \\
\text { (1993); } \\
\text { Alexander } \\
\text { (1985) }\end{array}$ & $\begin{array}{l}\text { Mathey (1982); } \\
\text { Ward (1982) } \\
\text { Keare\& Paris } \\
\text { (1993) }\end{array}$ \\
\hline $\begin{array}{l}\text { Types of self } \\
\text { help housing }\end{array}$ & & $\begin{array}{l}\text { Independent Self } \\
\text { Help }\end{array}$ & $\begin{array}{l}\text { Organised Self } \\
\text { Help }\end{array}$ & $\begin{array}{l}\text { Employed Self } \\
\text { Help }\end{array}$ \\
\hline \multirow{4}{*}{$\begin{array}{l}\text { People } \\
\text { involved }\end{array}$} & Families & $v$ & $v$ & \\
\hline & Neighbours & $v$ & & \\
\hline & Authorities & & & $\checkmark$ \\
\hline & Consultants & & $v$ & $\checkmark$ \\
\hline Organisation & & $\nu$ & $\checkmark$ & $\checkmark$ \\
\hline \multirow{2}{*}{$\begin{array}{l}\text { Method of } \\
\text { construction }\end{array}$} & Self & $V$ & $V$ & \\
\hline & Hire labour & & & $V$ \\
\hline \multirow[t]{2}{*}{ Time frame } & Incremental & 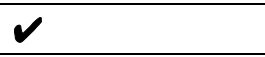 & & \\
\hline & Fully & & $v$ & $\checkmark$ \\
\hline \multirow{2}{*}{$\begin{array}{ll}\text { Supply } & \text { of } \\
\text { materials } & \end{array}$} & Incremental & $V$ & $V$ & \\
\hline & $\begin{array}{l}\text { Sponsored } \\
\text { by } \\
\text { authorities/ } \\
\text { other }\end{array}$ & & & $r$ \\
\hline
\end{tabular}

A number of studies have identified new low cost materials, new technologies as well as new housing designs to be used in supplying low cost houses (Wan Mohamed, 2015). However, the substance of the issue in self build housing is to initiate independency of acquiring a house on their own, beyond the assistance or aid given by government or private sector. This would provide freedom to dwellers in the major decision making on their house designs, construction and financial management. 


\subsection{The Self Build Housing for Malaysia}

A study has been made at the rural areas of Kedah, Malaysia which foster participatory approach using a simplified construction prefab system. It allows flexibility and strengthens the capacity of end-users to plan and manage their actions. The objective of the paper is to illustrate the rural households' responses in the identified areas towards the concept of self build housing through the introduction of a simplified prefabricated system to the selected respondents and to gather responses on the usage of the system.

\subsection{METHOD OF STUDY}

This study is designed into two phases. The first phase involved a questionnaire survey to collect information about the respondents' background and inclination as well as experience and skills in self build housing which was administered on a total of 501 rural households from two districts in Kedah. Through the use of purposive sampling, the population was identified from the Housing Loan Division of the Ministry of Housing and Local Government. Due to accessibility issues to the researcher, Districts in Kedah i.e. Padang Terap and Baling were chosen as the study areas as they have the highest number of applications for housing loans comprising medium poor and poor families. Descriptive survey was conducted to ascertain the opinions of the respondents on self build housing as an alternative. The second phase of the study involved the development of a simple prefabricated system. In order to gauge the responses on the ease of the construction of the system another survey was conducted. A quota sampling was then conducted through the pre-selected criteria and the respondents' selection was assisted by the headsman of the villages. The questionnaires were distributed to the respondents only after their involvement in assembling the system. This paper intends to highlight the responses gathered in this second phase.

\subsection{FINDINGS AND DISCUSSION}

A total of thirty three (33) respondents completed the questionnaire. Table 2 summarises the profiles of the respondents in terms of their age, skill and experience in construction. During the data collection, the researcher realised that majority of the respondents have had training, skill or experience in construction at some point in their lives. However, level of such skills or experience was not determined.

Table 2: Frequency and Percentage in Skills and Experience in Construction

\begin{tabular}{|l|c|c|c|c|}
\hline \multicolumn{1}{|c|}{ Age } & \multicolumn{2}{|c|}{ Skills in construction } & \multicolumn{2}{c|}{$\begin{array}{c}\text { Experience in } \\
\text { construction }\end{array}$} \\
\hline Mean $=31.8$ & Yes -21 & $63.63 \%$ & Yes -24 & $72.72 \%$ \\
\hline Min $=16$ & No -12 & $36.37 \%$ & No -9 & $27.28 \%$ \\
\hline Max $=60$ & Total -33 & $100 \%$ & Total -33 & $100 \%$ \\
\hline
\end{tabular}

An investigation on the understanding of technical topics on the proposed self build system is required as it would assist in determining some of the technical issues related to the system. The questions that were posed relate to the issue and they include: the ability to understand the illustrated manual instructions, drawings, ease of assembling the system using bolts and nuts, weight and height of the modular panels and ability to assemble the panels in the self build system on their own. The respondents were asked on a 4-point Likert scale as shown in Table 3. 
Table 3: The Four-Point Likert scale

\begin{tabular}{|c|c|c|}
\hline Scale & Range & Interpretation \\
\hline 4 & $3.01-4.00$ & Very Agree \\
\hline 3 & $2.01-3.00$ & Agree \\
\hline 2 & $1.01-2.00$ & Disagree \\
\hline 1 & $0.01-1.00$ & Very Disagree \\
\hline
\end{tabular}

Table 4 shows that the respondents had no major technical issues during the assembling of the self build system. This is maybe due to the fact that more than 50 percent of the respondents had either skills or experience or both in construction trade. Only a small percentage had stated that they may require assistance during the assembly even though the illustrated manual was provided and the drawings were comprehensible.

Table 4: Response on Technical Issues of the Self Build System

\begin{tabular}{|c|c|c|c|c|c|}
\hline \multirow[b]{2}{*}{ QUESTIONS } & \multicolumn{4}{|c|}{ Likert-scale } & \multirow[b]{2}{*}{ TOTAL } \\
\hline & $\begin{array}{c}1 \\
\text { (very } \\
\text { disagree) }\end{array}$ & $\begin{array}{c}\mathbf{2} \\
\text { (disagree) }\end{array}$ & $\begin{array}{c}\mathbf{3} \\
\text { (agree) }\end{array}$ & $\begin{array}{c}\mathbf{4} \\
\text { (very } \\
\text { agree) }\end{array}$ & \\
\hline $\begin{array}{l}\text { Q6 - able to read } \\
\text { instructions }\end{array}$ & - & - & 23 & 10 & $\begin{array}{l}100 \% \\
\text { agree }\end{array}$ \\
\hline $\begin{array}{l}\text { Q7 - drawings easy to } \\
\text { understand }\end{array}$ & - & - & 22 & 11 & $\begin{array}{l}100 \% \\
\text { agree }\end{array}$ \\
\hline $\begin{array}{l}\text { Q8 - usage of bolts and } \\
\text { nuts ease assembly }\end{array}$ & - & - & 7 & 26 & $\begin{array}{l}100 \% \\
\text { agree }\end{array}$ \\
\hline $\begin{array}{l}\text { Q9 - floor panels easy to } \\
\text { manage by } 2 \text { persons }\end{array}$ & - & 1 & 24 & 8 & $\begin{array}{c}96.96 \% \\
\text { agree } \\
3.04 \% \\
\text { disagree }\end{array}$ \\
\hline $\begin{array}{l}\text { Q10 - wall panels is } \\
\text { manageable }\end{array}$ & - & - & 24 & 9 & $\begin{array}{l}100 \% \\
\text { agree }\end{array}$ \\
\hline $\begin{array}{l}\text { Q11 - need assistance } \\
\text { even drawings are } \\
\text { comprehensible }\end{array}$ & - & 8 & 16 & 9 & $\begin{array}{c}75.75 \% \\
\text { agree } \\
24.25 \% \\
\text { disagree }\end{array}$ \\
\hline $\begin{array}{l}\text { Q12 - assemble the } \\
\text { system with families and } \\
\text { friends }\end{array}$ & - & 1 & 25 & 7 & $\begin{array}{c}96.96 \% \\
\text { agree } \\
3.04 \% \\
\text { disagree }\end{array}$ \\
\hline $\begin{array}{l}\text { Q13 - the system is easy } \\
\text { to assemble generally }\end{array}$ & - & - & 18 & 15 & $\begin{array}{l}100 \% \\
\text { agree }\end{array}$ \\
\hline
\end{tabular}

This led to the question of which particular component in the self build system that was difficult or easy to handle. The questions were organised in such a way that respondents were able to rate using the following 4-point Likert scale as shown in Table 5. 
Table 5: The Four-Point Likert scale

\begin{tabular}{|c|c|c|}
\hline Scale & Range & Interpretation \\
\hline 4 & $3.01-4.00$ & Very difficult \\
\hline 3 & $2.01-3.00$ & Difficult \\
\hline 2 & $1.01-2.00$ & Easy \\
\hline 1 & $0.01-1.00$ & Very easy \\
\hline
\end{tabular}

The majority of the respondents had responded that the self build components were easily assembled although this system introduced a new method to construct a house (refer to Table 6). Generally, the roof structure had the highest percentage (18.19\%) of being difficult to assemble. Out of six (6) respondents, five (5) mentioned that the roof trusses were heavy and long to be lifted over the roof beam. Furthermore, it was also mentioned by respondents that the height of the roof allowed only certain people to be able to undertake such task.

Table 6: Percentage of Ease of Assembly

\begin{tabular}{|l|c|c|c|c|c|}
\hline \multirow{2}{*}{ QUESTION 14 } & \multicolumn{4}{|c|}{ Likert-scale } \\
\cline { 2 - 5 } & $\begin{array}{c}\mathbf{1} \\
\text { (very } \\
\text { easy) }\end{array}$ & $\begin{array}{c}\mathbf{2} \\
\text { (easy) }\end{array}$ & $\begin{array}{c}\mathbf{3} \\
\text { (difficul } \\
\text { t) }\end{array}$ & $\begin{array}{c}\mathbf{4} \\
\text { (very } \\
\text { difficult } \\
\text { ) }\end{array}$ & TOTAL \\
\hline $\begin{array}{l}\text { a. Main structural } \\
\text { components (columns } \\
\text { and beams) }\end{array}$ & 15 & 17 & 1 & - & $\begin{array}{c}96.96 \% \\
\text { easy } \\
3.04 \% \\
\text { difficult }\end{array}$ \\
\hline b. Wall modules & 13 & 17 & 3 & - & $\begin{array}{c}90.90 \% \\
\text { easy } \\
9.01 \% \\
\text { difficult }\end{array}$ \\
\hline c. Floor modules & & & & & $\begin{array}{c}96.96 \% \\
\text { easy }\end{array}$ \\
& 18 & 14 & 1 & - & $\begin{array}{c}3.04 \% \\
\text { difficult }\end{array}$ \\
\hline d. Roof structure & & & & & $81.81 \%$ \\
easy \\
\end{tabular}

One of the advantages mentioned earlier in this paper is the flexibility of the self build system in terms of its spatial planning, financial management and design. This investigation has led to a series of questions on flexibility in relation to the self build system. The outcome of the investigation showed that nearly 100 percent of the respondents agreed that the self build system gave that flexibility in spatial planning and design except for one (1) respondent who believed that even though the system was designed to be incremental, he would still have difficulty in managing his financial resources (refer to Table 7). 
Table 7: Identifying Preferences in Flexibility Aspects of the Self Build System

\begin{tabular}{|c|c|c|c|c|c|}
\hline \multirow[b]{2}{*}{ QUESTIONS } & \multicolumn{4}{|c|}{ Likert-scale } & \multirow[b]{2}{*}{ TOTAL } \\
\hline & $\begin{array}{c}1 \\
\text { (very } \\
\text { disagree) }\end{array}$ & $\begin{array}{c}\mathbf{2} \\
\text { (disagree) }\end{array}$ & $\begin{array}{c}\mathbf{3} \\
\text { (agree) }\end{array}$ & $\begin{array}{c}\mathbf{4} \\
\text { (very } \\
\text { agree) }\end{array}$ & \\
\hline $\begin{array}{l}\text { 19. Flexibility in } \\
\text { arranging spaces }\end{array}$ & - & 1 & 22 & 10 & $\begin{array}{c}96.96 \% \text { agree } \\
3.04 \% \\
\text { disagree }\end{array}$ \\
\hline $\begin{array}{l}20 . \text { Flexibility in } \\
\text { managing financial }\end{array}$ & - & - & 24 & 9 & $100 \%$ agree \\
\hline $\begin{array}{l}\text { 21. Flexibility in } \\
\text { arranging façade design }\end{array}$ & - & - & 21 & 11 & $100 \%$ agree \\
\hline $\begin{array}{l}\text { 22. Investment in } \\
\text { prefabricated timber } \\
\text { house is good }\end{array}$ & - & - & 18 & 15 & $100 \%$ agree \\
\hline
\end{tabular}

An open-ended question was then posed to seek the respondents' opinion on the comparison of the self build system with other conventional houses. 93.9 percent believed that the simplified self build system was more attractive due to its straightforwardness in construction. Besides the ease of assembly, the respondents also found the self build housing system was a rapid form of construction (36.4\%), had good design values (27.3\%), while affordability and usage of timber design for the self build housing seemed to be less appealing. Surprisingly, only one (1) respondent (3\%) was convinced that the self build system had contributed to self help activities (refer to Figure 1).

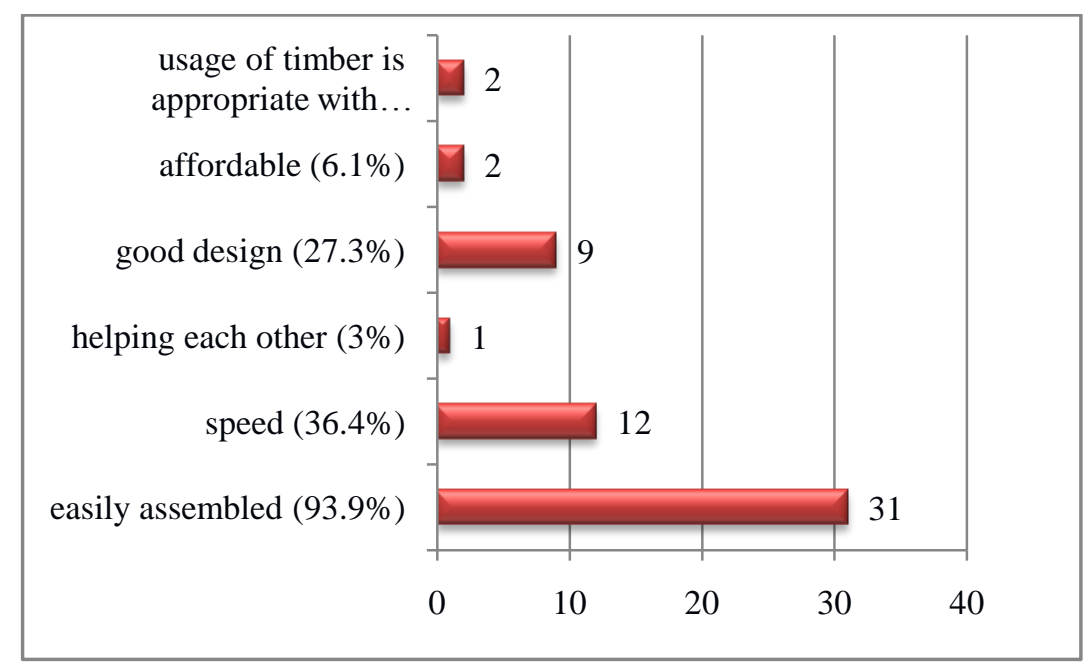

Figure 1: Investigating Opinions on the Self Build System vs. Conventional System

The subsequent section of the questionnaire attempts to associate the process of using the simplified self build system with any notable issues related to the process, such as costs, its responsiveness in rural area and again on speed and straightforwardness of the construction. Table 8 provides the summary of the responses. 
Table 8: Identifying Issues in Self Build Process Using the Self Build System

\begin{tabular}{|c|c|c|c|c|c|}
\hline \multirow[b]{2}{*}{ QUESTIONS } & \multicolumn{4}{|c|}{ Likert-scale } & \multirow[b]{2}{*}{ TOTAL } \\
\hline & $\begin{array}{c}1 \\
\text { (very } \\
\text { disagree) }\end{array}$ & $\begin{array}{c}\mathbf{2} \\
\text { (disagree) }\end{array}$ & $\begin{array}{c}\mathbf{3} \\
\text { (agree) }\end{array}$ & $\begin{array}{c}\mathbf{4} \\
\text { (very } \\
\text { agree) }\end{array}$ & \\
\hline 1. Saves building costs & - & - & 20 & 13 & $\begin{array}{l}100 \% \\
\text { agree }\end{array}$ \\
\hline $\begin{array}{l}\text { 2. Encourage in rural } \\
\text { area }\end{array}$ & - & 5 & 13 & 15 & $\begin{array}{c}84.84 \% \\
\text { agree } \\
15.16 \% \\
\text { disagree }\end{array}$ \\
\hline 3. Fast & - & 1 & 18 & 14 & $\begin{array}{c}96.96 \% \\
\text { agree } \\
3.04 \% \\
\text { disagree }\end{array}$ \\
\hline 4.Easy to construct & - & - & 21 & 12 & $\begin{array}{l}100 \% \\
\text { agree }\end{array}$ \\
\hline $\begin{array}{l}\text { 5. Buy a house from "a } \\
\text { box" }\end{array}$ & - & 3 & 22 & 8 & $\begin{array}{c}90.90 \% \\
\text { agree } \\
9.10 \% \\
\text { disagree }\end{array}$ \\
\hline
\end{tabular}

After acknowledging that the self build system eliminates the labour cost, all the respondents agreed that this system has the potential of saving money, and provides an easy way to construct a house although one (1) respondent $(3.04 \%)$ concluded that it still is not fast enough to house the needy. A radical idea was presented to the respondents on buying a house from a box, such that has been done through BoKlok IKEA's home or Sears and Roebuck houses (Wells, 1993; Wan Mohamed, 2009). 90.9 percent were excited and agree to invest if such house does exist in Malaysia.

A further investigation was made to ascertain willingness to be involved in public participation for self help housing that introduces this simplified system. $97 \%$ of the respondents agreed to participate in such activities. For those who were willing to be involved in self help housing gave various reasons, which are summarized in Figure 2.

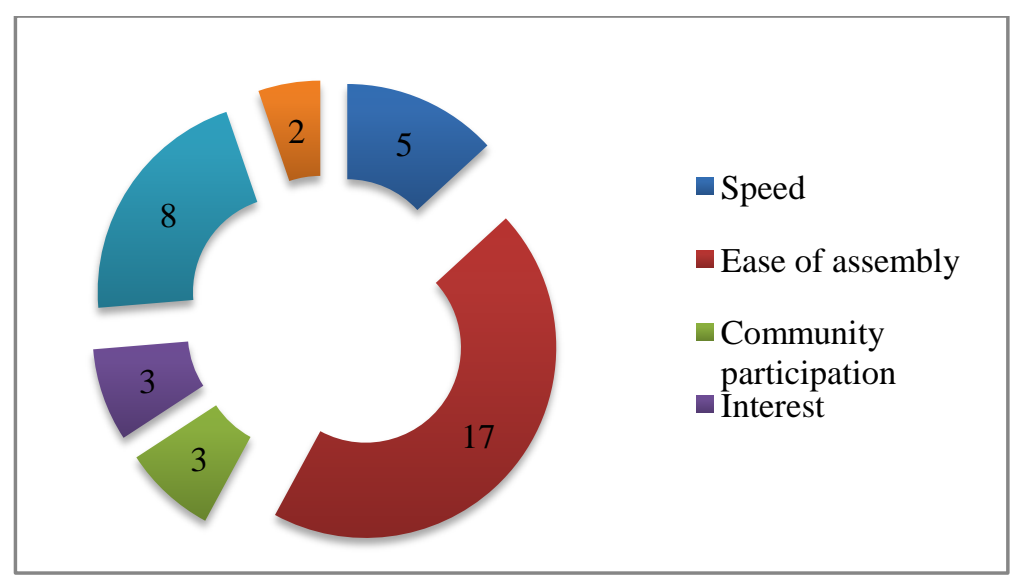

Figure 2: Reasons to Join Self Help Housing Activities 


\subsection{CONCLUSION}

This study has attempted to introduce the various forms of self build housing system that have been developed worldwide as the means to improve the quality of life for everyone in the communities especially low income households. In particular, this study has introduced a self build system as a means to initiate independency of rural households of owning houses in absence of the assistance from the relevant parties for the rural area in Kedah, Malaysia.

Through the responses gathered from the identified respondents in the study area, it can be concluded that the self build system for rural housing could function as one of the options or alternatives to meet certain criteria or requirements for the low-income household. The many requirements may include: to reduce cost, flexibility in space planning, ease of construction, mobility of the structure, variety of designs and commitments from the community through self help housing. Positive responses from the majority of the respondents were overwhelming towards the self build housing system introduced in the study.

Initiatives of community participation have significance values when existing practices are implemented by established community institutions, rather than trying to create new structures and mechanisms. Self help activities have been known to exist among the rural societies for decades. It is a matter of reviving such activity to a different level for different purpose using existing community assets and knowledge to develop agencies that are able to promote positive community attitudes towards collaboration and collective decision-making. The act of empowerment in self build housing could be one of the sustainable values embedded among the rural society. Self build houses are not just about shelter and security; they are about expressing oneself and changing one's lifestyle.

As prefabricated system seems to be one of the sought-after solutions to solve the provision of low cost housing in Malaysia, it is hope that other than mass producing these monotonous appearances for the future, a more individualised form through self help method could be implemented as part of the public housing policy.

\subsection{REFERENCES}

Agus, M.R. (2001) PerumahanAwam di Malaysia: DasardanAmalan. Kuala Lumpur, Utusan Publications \& Distributors Sdn Bhd.

Alexander, C. et. al (1985) The Production of Houses. New York, Oxford University Press.

Bakhtyar, B.; Zaharim, A., Sopian, K.; Moghimi, S. (2013). Housing for Poor People: A Review on Low Cost Housing Process in Malaysia. WSEAS Transactions on Environment and Development. 2 (9), pp.126-136.

Brundtland, G.H. (1987) Our common future: Report of the World Commission on Environment and Development. Oxford, UK: Oxford University Press.

Eccleshare, P., Harris, C., Riffat, S.(2005). Environmentally Sustainable Housing in the East Midlands. Building and Social Housing Foundation, University of Nottingham,.Centre for Alternative Technology, Nottingham.

Fraser, R. \& Platt, S. (1995). You Build: A Guide to Building Your Own Home. WSSBT Press, London.

Habitech Centre AIT (1996). Self Contained Housing Delivery System. Conference Habitat II City Summit, Istanbul.

Habraken, N.J. (1975) Design for Adaptability, Change and User Participation Unpublished paper

Haris, C. and Borer, P. (2005). The Whole House Book: Ecological Building Designs and Materials, Centre for Alternative Technology Publications.

Koones, S. (2005). Modular mansions (1st ed. ed.). Salt Lake City: Gibbs Smith.

Poh, Rosalynn (2009). 'Recyclable' Abodes. The Edge: Haven. Issue No 37, June-July 2009.

Porteous, C. (2002). The New Eco-Architecture: Alternative from the Movement.Spon Press, London. 
Serageldin, I. (1997). The Architecture of Empowerment: People, Shelter and Liveable Cities, Academy Editions, USA.

Tan, L.M. and Ingemann, D. (1991). Self Help Housing in Victoria. Metropolis in Ascendancy: Housing and Population: a Collection of Papers from Metropolis '90, Melbourne Australia, 1991, p.149-158.

Turner, J.F.C. (1972), Freedom To Build: Dweller Control of the Housing Process. New York, Macmillan.

Wan Mohamed, W.S., Ahmad, Y,et. al. (2015), "Prefab Materials For Self Build Housing System In Malaysia", Applied Mechanics and Materials, Vol. 747, pp. 250-253.

Wan Mohamed, W.S. and Ahmad, Y. (2009), "Prospective of Prefabrication System In Self Build Housing: Is It Possible In Malaysia?", Proceedings for the $4^{\text {th }}$ ASEAN Post-Graduate Seminar (APGS) at University of Malaya. 14-16 April 2009, by Faculty of Built Environment, UM.

Wan Mohamed, W. S., Yahaya, A.; Yusof, N. (2005). Towards Self Help Housing for Low Income Group in Malaysia. Second ASEAN Post Graduate Seminar, UniversitiMalaya, Kuala Lumpur.

Wells, J. (1993). "Appropriate Building technologies: An Appraisal based on case studies of building projects in Senegal and Kenya." Construction Management and Economics 11: 203-216.

Yusoff, N. (1995). A Culturally Appropriate and Economically Sustainable Housing Delivery System for Malay Urban Low-income Households in Malaysia. PhD thesis, Texas A \& M University, USA. 